\title{
The Modern Capitalist World Economy: A Historical Overview
}

\section{Citation}

Frieden, Jeffry. 2012. "The modern capitalist world economy: A historical overview." In The Oxford Handbook of Capitalism, ed. Dennis Mueller, 17-37. New York: Oxford University Press.

\section{Published Version}

10.1093/oxfordhb/9780195391176.013.0002

\section{Permanent link}

http://nrs.harvard.edu/urn-3:HUL.InstRepos:33490997

\section{Terms of Use}

This article was downloaded from Harvard University's DASH repository, and is made available under the terms and conditions applicable to Other Posted Material, as set forth at http:// nrs.harvard.edu/urn-3:HUL.InstRepos:dash.current.terms-of-use\#LAA

\section{Share Your Story}

The Harvard community has made this article openly available.

Please share how this access benefits you. Submit a story.

Accessibility 


\section{ORIGINS}




\section{THE MODERN CAPITALIST WORLD ECONOMY: A HISTORICAL OVERVIEW}

\section{JEFFRY A. FRIEDEN}

CAPITALIST economic activities are of very long standing-some would say they were present in proliferation during Roman times. ${ }^{1}$ By the late medieval and early modern period, large areas of Western Europe had thriving, relatively free markets for labor and capital, both in the city and in the countryside. We can most fruitfully and confidently speak of the full flowering of modern capitalism once it became a truly international economic order. That epoch evolved over the course of the sixteenth, seventeenth, and eighteenth centuries, as capitalism expanded from a limited Western European base to affect much of the world, from the Americas to East Asia.

\section{A Mercantilist World Economy}

Market economies flourished in many parts of Europe during the high and late Middle Ages, most prominently in Italian commercial and manufacturing centers 
such as Genoa, Venice, and Tuscany. Although they relied heavily on long-distance trade, these islands of capitalism had little structural economic impact on the rest of the world. But after the 1450s, the Ottoman Empire's control of the Eastern Mediterranean drove Europeans out into the Atlantic, and eventually around the world, in search of trade routes. Western Europeans' eventual recognition of the economic potential of the New World and of more consistent interaction with Africa and Asia opened a new era.

For nearly four centuries, from the mid-140os to the mid-18oos, the rest of the world was drawn into an economic and political order dominated by European capitalism. This order was organized around the overseas colonial empires of the Atlantic powers: first Spain and Portugal, then the Netherlands, England, and France. This was the first true international economy, and it was controlled in a very particular manner by its European founders. The economic system they built has come to be known as mercantilism.

Mercantilist ordering principles defined the international capitalist economy for several hundred years. Although there was variation among the principal mercantilist powers, the system's main features were common to all. First and foremost, mercantilism depended on substantial government involvement in the economy. These were, after all, colonial systems, and military might underpinned the predominance of the colonial powers over their possessions. But that was not all. Mercantilist governments considered their economic policies to be part and parcel of broader national goals, especially in the continuing struggle for diplomatic and military supremacy. Mercantilism enriched the country and the Crown, which then used those riches to build up military force. "Wealth is power," wrote English philosopher Thomas Hobbes, "and power is wealth." One of his fellow mercantilist thinkers drew the connections: "Foreign trade produces riches, riches power, power preserves our trade and religion."

The mercantilist economic order relied on systematic government intervention in the economy, particularly in international economic transactions. Although there was variation among countries and over time, core mercantilist goals and policies were similar. Mercantilist governments tried to stimulate demand for domestic manufactures and for such national commercial and financial services as shipping and trade. They did this, typically, by requiring their colonies to sell certain goods only to the mother country (the "metropole") and buy certain other goods only from the mother country. Restrictions on trade turned the terms of trade against the colonies: prices of colonial exports were depressed, while prices of colonial imports were elevated. This, of course, benefited metropolitan producers, who could purchase their inputs (raw materials, agricultural products) at artificially low prices and sell their output (manufactures) at artificially high prices. Virginia tobacco farmers had to sell their leaf to London, although Amsterdam would have paid more; they had to buy their cigars from London, although Amsterdam would have charged less. The rents created this way went to enrich the manufacturers and "merchant princes," whose alliance with the Crown characterized the mercantilist political economy. 
Mercantilist governments also required many international economic transactions to be carried out by their preferred, national agents: shipping, insurance, finance, wholesale trade. In some cases, trade had to be channeled through certain favored ports. Like import and export restrictions, this provided rents to the privileged. The colonial governments also endeavored to discover and exploit precious metals. The Crown usually took (or taxed very heavily) the gold and silver discovered in the colonies. Mercantilist governments typically chartered monopolistic enterprises to which they delegated both economic and administrative functions in the colonies, such as the Hudson's Bay Company and the Dutch East India Company.

Mercantilist policies achieved several interrelated goals. They provided revenue for the government. This might come directly from precious metals and other forms of tribute or indirectly from the revenue provided by those enriched by the policy. This was one sense in which mercantilist economic policies supported the broader diplomatic and military goals of the government: they made available the wherewithal to sustain and increase national power. Mercantilist policies also aimed explicitly at encouraging early manufacturing, seen as central to modern economic and military advance. ${ }^{3}$ And the restraints on trade and monopolistic charters cemented ties between the government and its powerful supporters in business.

The political economy of mercantilism was largely based on an implicit or explicit alliance between the government-the Crown, except in the Dutch Republic-on the one hand, and the merchants, manufacturers, and investors that carried out the bulk of economic interactions with the colonies on the other. ${ }^{4}$ The character of this alliance varied from country to country. In the Netherlands, the mercantile classes effectively and directly controlled the state; in the other colonial powers, the government had interests of its own, which sometimes conflicted with those of its business allies. The Spanish Crown, for example, was particularly concerned with consolidating its control over the country, which was only fully freed of Muslim rule in 1492, and in which there were powerful regional noblemen. This made the Spanish Crown more insistent on centralizing control and revenue and less willing to encourage the rise of powerful private actors than many other mercantilist rulers.

Mercantilist policies benefited the favored metropolitan businesses, at the expense of the colonies (and consumers). To be sure, some colonial subjects valued membership in a powerful empire, especially inasmuch as the empire protected them from others. While many citizens of Great Britain's North American colonies chafed at mercantilist restrictions on their trade, many others appreciated the security British naval and military power provided.

The mercantilist era's main characteristics highlight enduring features of modern capitalist economies. The first is an ambivalent relationship with the world economy. To be sure, the leading colonial powers were heavily oriented toward engagement in the international economy and eager to take advantage of what the rest of the world economy had to offer. At the same time, mercantilist policies were highly nationalistic and strongly protected the home market and national producers from foreign competition. This tension, between the desire to take advantage of international economic opportunities, on the one hand, and the fear of harm 
from foreign competition, on the other, is a recurring theme in capitalist attitudes toward the world economy. The mercantilist powers dealt with the issue by aggressively expanding their access to foreign markets, but jealously guarding and protecting the markets they conquered within their colonial empires.

A second feature of the mercantilist experience was the tension between state and markets. In the mercantilist period, as at other times, market actors wanted economic freedom, and governments wanted the prosperity markets could provide. Indeed, markets were almost certainly much better developed and much freer in this era than they had been in the previous medieval centuries. At the same time, mercantilist governments were aggressive in their intervention in the economy. To some extent this reflected real or imagined demands of national security and military power, in an attempt to harness economic dynamism to national goals. To some extent it reflected the interests of powerful economic interest groups, which were enriched by state-enforced monopolies, state controls on trade, and the backing of their governments. The result was a mix of state intervention and market development-not always harmonious.

Indeed, these two dimensions have been at issue throughout the history of capitalism. The first is the international-national dimension: the conflicting desire for integration with and insulation from the world economy. The second is the statemarket dimension: the conflicting desire for government involvement in markets and market freedom from government. Over time, both countries and the world in general have oscillated between periods of greater and lesser economic openness and between periods of greater and lesser government intervention in the economy.

Mercantilism reflected the economic and political realities of its era. Western European economies had advanced enough beyond those in the rest of the world, both in technology and in organization, that their predominance was largely unchallenged. Meanwhile, previously unimaginable overseas economic prospects had opened up, a whole world of resources and markets that could be tapped and, in most cases, controlled. This provided the incentive, to rulers and capitalists alike, to assert themselves wherever possible. At the same time as the mercantilist powers were subjugating vast areas to their colonial control, they engaged in continuing conflicts with one another for supremacy. This gave them powerful motivations to use their colonies to enhance their military might and to use their military might to amass more colonies. Domestically and internationally, at home and abroad, the mercantilist systems generally reflected a mutually rewarding partnership between rulers and capitalists, enriching both and drawing most of the world into their orbit.

\section{The End of Mercantilism}

A combination of political and economic developments began to erode the mercantilist system. Politically, one of the attractions of mercantilist policies had been 
their connection to the struggle for diplomatic supremacy: reserving access to colonies to the home country and restricting it to others served to help the government amass resources for military purposes and to deny resources to real or potential enemies. But in 1815, a British-led alliance defeated Napoleon at Waterloo and effectively ended three centuries of warfare among the Atlantic powers. With British maritime supremacy ensured, and the Continent largely stable, the military arguments for mercantile colonialism faded.

Domestic political trends also undermined the mercantilist system. Throughout Western Europe, autocratic dynastic rule came under challenge, largely from the rising business and middle classes. Although political reform was slow, and certainly did not result in anything we would recognize as democratic, it did loosen the exclusive grip on power of some previously favored groups. Among these were the monopolistic enterprises created and favored by mercantilist policy, whose preferential position was increasingly resented by more modern entrepreneurs in industry, trade, and finance. As the foreign policy arguments for mercantilism faded, so did the domestic political alliances underpinning it.

Economic trends also eroded the previous political economy. Most important was the rise of modern industry. Manufacturing in the earlier era, though certainly an advance over the medieval norm, was on a small scale, often based on cottage industry. Over the course of the eighteenth and early nineteenth centuries, manufacturing was fundamentally transformed, especially in Great Britain and some areas of Northern Europe. A flurry of technological innovations revolutionized production. Employers brought dozens, even hundreds of workers together in large factories to use new machinery, new energy sources, and new forms of organization. Power looms and mechanical spinners transformed the textile industry. Improvements in the use of water power, and eventually the development of steam power, made the machinery more powerful still. The Industrial Revolution and the rise of the modern factory system meant that the new industries could undercut competitors in virtually every market, which made mercantilist barriers to trade either irrelevant or harmful.

Great Britain led the way in gradually jettisoning mercantilism. As British military predominance was secured, both Crown and Parliament were less concerned about tight colonial control. Many in Britain had indeed, as far back as the American Revolution, begun to regard the cost of keeping the colonies as outweighing the benefits. As Parliament, increasingly representative of business and middle-class interests, imposed ever greater restrictions on royal prerogatives, it increasingly challenged the royally chartered monopolies.

As the British economy evolved, dissatisfaction with mercantile controls grew. British industrialists wanted to eliminate the country's trade barriers. Removing restrictions on imports would allow British producers access to cheaper inputs and would give British consumers access to cheaper imported food, which would allow factory owners to pay lower wages without reducing workers' standard of living. At the same time, industrialists believed that removing trade restrictions would increase world demand for British goods. For these reasons, Britain's 
manufacturing classes and regions developed an antipathy to mercantilism and a strong desire for free trade.

As the city of London became the world's financial center, it added its influence to that of other free-trade interests. Britain's international bankers had a powerful reason to open up the British market to foreigners: the foreigners were their customers. American or Argentine access to the thriving British market would make it easier for Americans and Argentines to service their debts to London. The industrial and financial interests mounted a concerted attack on what antimercantilist crusader Adam Smith called "the mean and malignant expedients of the mercantile system." ${ }^{\text {B }}$ By the 1820 s those "malignant" mercantilist expedients were under constant challenge.

The battle over mercantilism was joined especially over the Corn Laws, tariffs imposed during the Napoleonic Wars on imports of grain. ${ }^{6}$ Industrialists and financiers opposed the agricultural tariffs, as did the urban middle and working classes, and were opposed by the country's powerful farmers. The free traders won after a protracted struggle. They might not have prevailed had there not been a major reform of British political institutions: a changed electoral system that reduced the power of farm constituencies and increased that of the cities and their middle-class residents. Even with the electoral reforms in place, the final votes in 1846 and 1847 were extremely close and tore the Conservative Party apart. A few years later, Parliament repealed the last vestiges of British mercantile controls on foreign trade.

\section{The Classical Era: Free Trade and THE GOLD STANDARD}

After Britain, the world's most important economy, discarded mercantilism, most of the other major economic powers followed suit. In 1860, France joined Great Britain in the Cobden-Chevalier Treaty, which freed trade between them and helped draw the rest of Europe in this direction. As the German states moved toward unification in 1871, they created a free trade area among themselves, then opened trade with the rest of the world. Many New World governments also liberalized trade, as did the remaining colonial possessions of the free-trading European powers. Mercantilism was dead, and integration into world markets was the order of the day.

Over the course of the nineteenth century, much of the world opted for general openness to the international economy and for a reduced level of state involvement in the economy. Although mercantilism had been marked by a strong role for the government in both domestic and international economic affairs, the classical order that arose over the course of the 1800 s saw a dramatic reduction in government involvement on both dimensions. 
Technological change dramatically reduced the cost of international economic exchange, making an open economy that much more attractive. Over the course of the century telegraphs, telephones, steamships, and railroads replaced horses, carrier pigeons, couriers, and sails. The railroad fundamentally changed the speed and cost of carrying cargo over land. The steamship revolutionized ocean-going shipping, reducing the Atlantic crossing from over a month in 1816 to less than a week in 1896.

The new technologies took hold and diffused very rapidly, even in developing regions. In 1870, Latin America, Russia, Canada, Australia, South Africa, and India combined had barely as much railroad mileage as Great Britain. By 1913, these regions had ten times Britain's railroad mileage. Argentina alone went from a few hundred miles of rail in 1870 to a system more extensive than Britain's. ${ }^{8}$ On the seas, there was a twentyfold increase in the world's shipping capacity during the nineteenth century. ${ }^{9}$

These advances reduced the cost of land transportation by more than four-fifths and of sea-going transport by more than two-thirds. Europe flooded the world with its manufactures and was in turn flooded with farm products and raw materials from the prairies and the pampas, the Amazon and Australia. Over the course of the 180os, the trade of the advanced countries grew twice to three times as fast as their economies; by the end of the century, trade was seven or eight times as large a share of the world's economy as it had been at the beginning of the century. ${ }^{10}$

International investment also soared. As telegraphy allowed information to be transmitted instantaneously from any reasonably developed area to investment houses and traders in London, Paris, and Berlin, new economic opportunities attracted the interests of European savers like never before. Foreign capital flooded into rapidly growing regions in the New World, Australia, Russia, and elsewhere. By the early 1900s, foreign investments, largely in bonds and stocks, accounted for about one-third of the savings of the United Kingdom, one-quarter of France, and one-tenth of Germany. ${ }^{11}$ This was also an era of virtually free international immigration, at least for Europeans. Some fifty million Europeans moved abroad, along with another fifty million Asians. Markets for goods, capital, and labor were more tightly linked than they had ever been.

Perhaps the most striking, and most powerful, organizing principle of global capitalism during the nineteenth century was the gold standard. After centuries of stable bimetallism, in the 1870 governments were faced with a choice. New silver discoveries drove the price of silver down and made the existing rate of exchange between the two metals unstable, so governments had to either change the rate or choose between gold and silver. Meanwhile, as international trade and investment grew, gold-the traditional international medium of exchange-became more attractive than domestic silver. Finally, Great Britain had been on gold since 1717, and its status as the global market leader attracted other countries to use the same system. In the 1870 most major industrial countries joined the gold standard, with more countries joining all the time. By the early 190os, the only two countries of economic importance not on gold were China and Persia. 
When a country's government went "on gold," it promised to exchange its currency for gold at a preestablished rate. This provided an important degree of predictability for world trade, lending, investment, migration, and payments. The impact on trade was substantial; being on gold in this period is variously estimated to have raised trade between two countries by between 30 and 70 percent. ${ }^{12}$ The gold standard was even more important for international finance than it was for trade. International financiers regarded being on gold as an obligation of wellbehaved members of the classical world economy, a signal of a country's economic reliability. ${ }^{13}$ Investors had good reasons to focus on government commitments to the gold standard. The balance of payments adjustment mechanism under the gold standard might require a government whose economy was running a payments deficit to reduce wages and spending to move back toward balance. To stay on gold, governments had to be able to privilege international ties over domestic demands, imposing austerity and wage cuts on unwilling populations if necessary. This made the gold standard a litmus test that international investors used to judge the financial reliability of national governments. ${ }^{14}$ Membership in the gold club conferred a sort of blessing on its initiates, and gave participating countries access to an enormous pool of international savings.

Technological and policy change turned a world of closed colonial empires into an integrated global economy. The results were impressive by almost any standard. Transportation and communications improvements, along with policies to further economic integration, led to a significant convergence of prices. ${ }^{15}$ This in turn created important opportunities for countries to gain access to world markets for goods and capital. As railroads, steamships, and eventually refrigeration brought grain and beef prices in Omaha and Buenos Aires up toward European levels, rural backwaters quickly became some of the most attractive places in the world to farm and invest.

Economic integration also led to convergence of levels of development, as many of the countries drawn into this new world economy grew very rapidly. Industrialization spread from its Northwestern European homeland to the rest of Europe and much of the world. Great Britain was overtaken: in 1870, British iron and steel production was greater than that of Germany and the United States combined, while by 1913 Germany and the United States combined outproduced the United Kingdom roughly six to one. This was true also of living standards: per capita incomes in the United States, Australia, and New Zealand were higher than in the United Kingdom, and Argentina and Canada were gaining fast. ${ }^{16}$ Although there were periodic panics and recessions, the 100 years from 1815 to 1914 were marked by a general macroeconomic stability that matched the general stability of diplomatic affairs-which is why the era is often called the Hundred Years' Peace or the Pax Britannica.

Whatever its economic achievements, there were plenty of evils in the classical era. The end of mercantilism was associated with a decline of the early colonial empires, especially in the New World. But in the 188 os, the major powers began accumulating new colonial possessions. Europe's colonialists divided most of Africa, Southeast Asia, and East Asia among themselves (and Japan); the United 
States joined the fray in the Pacific and the Caribbean. Many of the new empires were run on lines reminiscent of mercantilism, giving preferential treatment to the colonial power's economic interests, although the monopolistic features were typically more muted. Some colonies were afforded reasonable treatment; but some were mercilessly exploited. The horrific abuses of Belgium's King Leopold in the Congo were particularly egregious (Hochschild 1998). In part as a result, many parts of the world-especially in Africa and Asia-stagnated or declined economically even during the best of times.

The classical economic order was also no political idyll. Leaving colonialism aside, political rights were severely limited even in the industrial world. Most of the developed nations made no pretense of being democratic; those that did had such restricted franchise and limited freedom that today we would not consider them democratic. Indeed, limited political voice by farmers and the middle and working classes may well have been essential to the ability of governments to play by the rules of the classical game: it is hard to imagine truly representative governments being able to impose the austerity measures necessary to sustain economic openness in a world largely without social safety nets.

The economic dislocations created by economic integration were also not trivial. As cheap farm products flooded into Europe from the New World, Australia, Russia, India, and elsewhere, most of the Continent's farmers were made redundant. For decades, much of Europe suffered through a wrenching agrarian crisis. Tens of millions left the land to resettle in the cities or move abroad. Others demanded protection from imports, and sometimes governments provided this. Foreign competition also harmed many traditional producers in the developing world, who could not compete with inexpensive factory products.

Nonetheless, despite problems and challenges, a recognizable economic order prevailed over most of the world in the nineteenth and early twentieth centuries. This order was almost the diametric opposite of mercantilism. Where the mercantilist system was based on aggressive closure of home and colonial markets to foreigners, the norm in the classical period was of openness to international trade, investment, and migration. Where mercantilism presumed extensive government intervention in the economy, both at home and abroad, governments in the classical system tended-with variations - to leave markets largely to their own devices. Both international openness and a market orientation were debated and contested, but both prevailed most of the time and in most countries.

The classical international economic order that reigned in the nineteenth and early twentieth centuries has to be considered generally successful. The world economy as a whole grew more in the 75 years before 1914 than it had in the previous 750 . There was a great deal of convergence as many poorer countries grew more rapidly than rich countries. Goods, capital, technologies, information, ideas, and people moved quite freely around the world. Macroeconomic conditions were stable overall, economic relations among the major economic powers were generally cooperative, and there was a broad consensus about the desirability of sustaining an open world economy. 


\section{The Interwar Collapse}

Despite the achievements of an integrated international economy in the previous century, it came to an end with World War I, and efforts to re-create it failed for the next twenty years. Instead, capitalism turned inward, in some cases toward the most insistently nationalistic policies in modern history. In much of the world, a general trend toward engagement with the world economy and in the direction of minimal government involvement in markets was reversed almost completely.

World War I had two profound and lasting effects. The first was to shift the center of gravity of the world economy definitively away from Europe and toward the United States. The war absorbed the energies of the European belligerents and drew them out of their colonial possessions. The United States rushed into the vacuum this created, supplying the belligerents with everything from food to weapons and supplanting the Europeans as principal traders, lenders, and investors in much of the developing world. By 1919, the United States had gone from being the world's largest debtor to its leading lender, and it was also the arbiter of the economic and political settlement worked out among the warring parties at Versailles.

The second enduring effect of the war was to change the political landscape of Europe. Although political institutions had gradually become more representative over the course of the previous century, on the eve of the war they remained quite limited. The war led to a remarkable increase in the depth and breadth of democratic reform, especially in Europe. In part this was due to the collapse of four autocratic empires - the Russian, Austro-Hungarian, Ottoman, and German - and their replacement by successor states, many of which were democratic. In part, democratization was a direct result of belligerent governments' attempts to garner support for the war effort, in particular from socialist parties and their workingclass bases of support. Many European governments rewarded popular backing for the war with some combination of political representation, social reform, and labor rights. By the early 1920 almost every industrialized nation was governed by a civilian democracy with universal male suffrage, and many had universal female suffrage as well. Largely as a result, over the course of the interwar years, Europe's socialist parties - generally anathema, often illegal, before 1914-were parliamentary fixtures and frequent members of ruling coalitions.

The rise to economic predominance of the United States had a number of implications. It symbolized a significant change in the nature of modern capitalism. By the 1920s, the United States had pioneered a path soon followed by other industrial nations, - toward an economy dominated by mass production and mass consumption. Some of this was the result of economic growth. As incomes rose, the demand for consumer goods beyond food, clothing, and shelter grew, especially to include more sophisticated consumer durables-including such recently invented ones as the radio, the phonograph, the telephone, the refrigerator, and the automobile. More and more of what industry produced was aimed at the general public. 
The ways industry produced evolved along with its products. Technological advances in production, especially the spread of electricity and electrical machinery, drove increases in the scale of manufacturing, including the use of the assembly line. Organizational developments gave rise to the modern multiplant corporation, integrating many stages of the production process; some of the new industrial corporations became multinational. Corporations grew, and oligopolies came to dominate many markets. At the same time, labor unions organized much larger shares of the labor force.

Where the typical industrial economy of the nineteenth century was characterized by small firms, family farms, and unorganized workers, by the 1920 s most major industrial economies were dominated by oligopolistic corporations and organized labor unions. Modern societies were driven by big business and big labor. The automobile industry was both typical of and in the forefront of the change: by the 1920s, motor vehicle production was the largest industry in most developed societies; the sector was dominated by large corporations and, in many instances, large labor unions.

In addition to the more general impact of American-style capitalism, the economic rise of the United States had some more specific effects. The United States largely determined the shape of the postwar settlement, as the Treaty of Versailles that ended the war largely followed the proposals of U.S. President Woodrow Wilson. These included institutionalized cooperation among the major powers, on economic issues as well as others. But almost as soon as the American blueprint was put in place, with the League of Nations and a series of monetary and economic conferences, the United States turned its back on the rest of the world. In 1920, a Republican Party committed to "isolationism" swept the presidency and both houses of Congress. The isolationists were hostile to international cooperation on economic matters that they felt would compromise U.S. autonomy.

The United States remained the most important trading, investing, and financial center in the world, but the government largely withdrew from international economic affairs. The impact of this was compounded by the enduring hostility among the former European belligerents. This made it extremely difficult for the major economic powers to work together on international economic issues.

The difficulties of interwar cooperation, and a more detailed examination of earlier experiences, demonstrated the importance of purposive collaboration to maintain an open international economic order. During the classical era, there had been a widespread belief that an integrated world economy was self-regulating and self-sustaining. Although this may have been true of some markets, and to a limited extent to the operation of the gold standard, it was clearly not the case with the global economic order itself. There had been very substantial cooperation among the major financial and monetary centers, especially in times of crisis. Monetary authorities lent substantial amounts to foreign governments facing financial difficulties and helped organize concerted efforts to stabilize markets.

More generally, the classical international economic order had depended on the willingness and ability of participant governments to adjust their domestic economic 
activities to international economic conditions. This meant, most important, allowing and reinforcing the austerity measures required to restrain-even reduce-wages and prices as necessary to maintain a national commitment to the gold standard. This in turn was possible due largely to the fact that those principally affected by this austerity-farmers, workers, the middle classes-tended to be underrepresented, or not represented at all, in the political systems of the classical era.

But the spread of democracy after World War I meant that most industrialcountry governments faced substantial political opposition to attempts to impose gold standard-style adjustments. ${ }^{17}$ Unlike in the nineteenth century, by the 1920 s farmers, workers, and the middle classes were well represented in national political systems and strongly resisted adjustment measures that had been imposed with relative ease in an earlier era. The classical system had been based on a consensus among elites in favor of an open international economic order. The national political economies that emerged from World War I largely lacked such a consensus.

The interwar years were marked by almost continual conflict among the major economies. Attempts at monetary cooperation were largely inconclusive or failures. Trade policies tended to become more protectionist over time. Important financial problems - such as war debts owed by the Allies to the United States, or reparations owed by the Germans to the Allies-created continual frictions.

Over the course of the 1920s, as economies recovered rapidly, political difficulties seemed less important. At the start, the immediate postwar years were very difficult in Central and Eastern Europe. The new successor states struggled to put their economies on a sound financial footing, often after suffering through several years of very high and hyperinflation. By the time Germany's hyperinflation was brought to an end in 1923, the price level was one trillion times what it had been in 1919. But by 1924, economic growth had been restored in most of the Continent and in the rest of the world. Over the next few years, countries gradually came back to the gold standard, international investment reached and surpassed the prewar levels, and international trade grew rapidly. Latin America and many of the more advanced colonies increased their primary exports dramatically and regained access to international capital markets-especially to loans from the new U.S. lenders. It appeared that the world economy had been restored in something similar to its former conditions.

However, the underlying weaknesses of the post-World War I settlement became painfully obvious when crisis hit in 1929. What started as a minor recession dragged on and on, exacerbated by growing conflict among the major financial centers. Debtors in Latin America and Central and Eastern Europe defaulted, exacerbating financial distress. Financial and currency crises raced through Europe, eventually driving most of the region's countries off gold. Desperate governments raised trade barriers, imposed capital controls, and restricted currency convertibility in an effort to combat the growing crisis.

From 1929 until 1936, virtually every attempt at a cooperative response to the crisis failed. Meanwhile, insistent government attempts to implement the kind of austerity measures that had worked reasonably well in the classical era ran into 
economic and political obstacles. Economically, gold standard-style adjustments had been relatively rapid in the nineteenth-century environment of small firms, small farms, and unorganized labor, which made for quite competitive markets and flexible prices and wages. But in the conditions of the 1930s, with industrial economies dominated by large firms in oligopolistic markets and well-organized labor unions, prices and wages were much less flexible. As a result, attempts to bring the economy back into balance by reducing wages and prices largely failed. Even when prototypical adjustment succeeded, in the new conditions it created a vicious circle that Irving Fisher called "debt deflation," in which deflation raised real debt burdens, which caused further bankruptcies and further deflation (Fisher 1933). Attempts to hew to gold standard orthodoxy simply worsened the downward spiral—and often heightened political tensions.

The new political realities of the industrial world also affected responses to the crisis that began in 1929. Governments could no longer ignore the impact of the crisis, or of austerity measures, on farmers, the middle classes, and the working classes, for these groups were now well represented in national politics. Attempts to fit national economies to their international commitments ran into powerful political opposition and often ended with the toppling of the government that tried to do so, whether by democratic or authoritarian means.

The result almost everywhere was a turn inward in trade, finance, and investment. In Southern, Central, and Eastern Europe, Japan, and Latin America, governments imposed high trade barriers, defaulted on their foreign debts, left the gold standard, and slapped on capital controls. Governments in these nations also typically began to play a more directive role in economic affairs, sometimes nationalizing large portions of the economy. The Soviet Union, which had jettisoned capitalism in 1917 but permitted some aspects of a market economy to persist, shut down these vestiges and embarked on a forced march toward industrialization under central planning. The order of the day was autarky-a classical Greek term recoined to mean a purposive economic policy of national self-sufficiency: trade protection, capital controls, an inconvertible currency. This was usually carried out by an authoritarian government-fascist in Central and Eastern Europe, communist in the Soviet Union, nationalist in Latin America-as almost all the preexisting democracies were swept away.

The new autarkic governments changed direction toward heavy-handed intervention in the economy and international economic relations, so much so that the policy was sometimes, and with some justification, called "neomercantilist." Yet developing and semi-industrial countries could hardly be faulted for falling back on their own resources: international trade dropped by two-thirds between 1929 and 1932, international finance was dead in the water, and the gold standard had largely been abandoned by its strongest proponents. The autarkies could, with some reason, argue that their turn inward was driven by the failure of the global capitalist economy.

Most of the principal economic centers had also largely abandoned their international commitments. In 1931, Great Britain left the gold standard, after more 
than two centuries on it, and so did most of Europe; the United States followed in 1933. Governments everywhere increased trade protection; even formerly freetrade Britain built tariff walls around its empire. Every attempt to cobble together some semblance of cooperation among the major economic powers failed.

It was only late in the 1930s that an alternative to autarky began to emerge in Western Europe and North America. Governments in these areas-which had largely remained democratic amid the flowering of authoritarianism-expanded their social policies, experimented with countercyclical macroeconomic policies, and gradually increased the role of the public sector. The new model, which eventually gave rise to the modern social democratic welfare state, attempted to blend markets with regulation, an open economy with social insurance. The governments involved also, by 1936, were recommitting themselves to international cooperation in commercial and monetary affairs, trying to bring down trade barriers and stabilize currencies. These attempts were halting and preliminary, but they pointed the way toward a new economic policy synthesis. General sympathy for a market economy and international economic integration coexisted with substantial government involvement in the economy, especially in macroeconomic management and social policy.

\section{Second Chance: The Bretton Woods System}

Even as World War II raged, the Allies planned the postwar economy, hoping not to repeat the experience of the aftermath of World War I. This time around, the United States was committed to both building and sustaining an open international economy-and although there remained plenty of isolationist Americans, postwar governments stayed this course. The result was the first international economic order whose general contours had largely been planned by governments, in this case the U.S. and British governments. Because the final negotiations over the arrangement were held in July 1944 at a resort in Bretton Woods, New Hampshire, it became know as the Bretton Woods System.

The Bretton Woods System reflected a general commitment by the capitalist allies (not the Soviet Union), and eventually by virtually all of the advanced industrial capitalist nations, to an open international economic order. All developed parties to the agreement shared the goal of generally free trade and investment and stable currency values. As the system evolved, the General Agreement on Tariffs and Trade (GATT, eventually succeeded by the World Trade Organization, WTO) oversaw a process of gradual trade liberalization. The International Monetary Fund (IMF) supervised monetary relations among member nations, providing balance of payments financing and encouraging generally stable exchange rates. The International Bank for Reconstruction and Development (IBRD or World Bank) financed long-term infrastructure projects that would facilitate private investment 
in developing countries. Together, these three Bretton Woods institutions watched over an integrated capitalist world economy, which would avoid the protectionism, financial disarray, and currency volatility of the interwar years. (The Soviet Union and its allies were not included in this system, as they had opted out of international capitalism.)

The Bretton Woods monetary order was centered on the U.S. dollar, fixed to gold at $\$ 35$ an ounce. Other currencies were fixed to the dollar but could be varied in the event "fundamental disequilibria" (never clearly defined) dictated a devaluation or revaluation. This was meant to provide both the currency stability that had been lacking in the interwar years and the flexibility that had been lacking in the classical era. In this way, it was something of a compromise. Governments were expected to abide by the rules of the balance of payments adjustment game, but not at the expense of important national economic goals.

The Bretton Woods System was replete with this sort of compromise. The system itself was, in the broadest sense, meant to reconcile a national commitment to economic integration with a parallel national commitment to demand management and the social democratic welfare state. These two sets of commitments had largely been seen as inconsistent under the gold standard and during most of the interwar period, but appeared both economically and politically desirable and obtainable by the $1940{ }^{18}{ }^{18}$ There were other compromises as well. Although trade was liberalized, this was achieved only gradually. Not only that, but agricultural and services trade were not included, the developing countries were exempt, and there were many escape clauses written into the agreements, which allowed governments to impose trade barriers in certain circumstances. The same spirit of gradualism and compromise was clear in financial affairs: although there was a general belief in the desirability of free capital movements, virtually all governments imposed capital controls of one sort or another to manage international payments.

The Bretton Woods System governed relations among the industrialized capitalist economies from the late 1940s until the mid-1970s. Over these twenty-five years, the capitalist world grew more rapidly that it had at any time in history. Real per capita GDP had risen 1.3 percent a year between 1870 and 1913, a rate vastly higher than anything previous seen; after dropping below 1 percent a year in the troubled interwar period, from 1950 to 1973 GDP per capita grew by more than 2.9 percent a year-more than twice as rapidly as during the classical age. This average was brought down by relatively slow growth in the developing world: Western Europe's GDP per person grew by more than 4 percent a year, Japan's by more than 8 percent a year. Even though the developing and noncapitalist worlds largely withdrew from international commerce, world trade overall grew twice as fast as world output. ${ }^{19}$ There is little question that this compromise between national macroeconomic management and international economic integration was extraordinarily successful.

The less developed countries (LDCs) of Asia, Africa, and Latin America did somewhat less well. Latin American nations were hit hard by the Great Depression and spent most of the subsequent twenty years building self-sufficient national 
markets. To some extent, this was forced on them by the Depression, World War II, and postwar reconstruction, all of which limited their foreign economic opportunities. But even after wartime conditions faded, Latin American governments maintained and increased their barriers to trade with the rest of the world. They did permit foreign direct investment by multinational corporations, but their principal policies were associated with what has been called import substituting industrialization (ISI), a systematic attempt to encourage domestic manufacturing to replace previously imported manufactured goods. Governments imposed high trade barriers, subsidized domestic manufacturing, taxed exports, took over large portions of basic industry, and generally biased economic incentives against exports and toward production for the domestic market.

As they decolonized, most of the former European colonies in Africa and Asia followed the Latin American example and pursued ISI. The result was a world largely divided in three parts: the industrialized capitalist nations, gradually increasing economic ties among themselves; the developing capitalist nations, growing quite separately from the world economy; and the centrally planned economies of the communist nations, which rejected most ties with the capitalist world. Each of these three segments of the world economy represented a different mix of state and market, openness and closure. The centrally planned economies rejected both markets and international economic integration. The capitalist LDCs accepted markets domestically, but their governments were deeply involved in their national economies and also cordoned themselves off from the rest of the world. The industrial capitalist countries pursued a modest compromise between state and market at home, and a general if restrained commitment to international economic integration.

\section{From Bretton Woods to Globalization}

These three approaches appeared stable for several decades. But over the course of the 1970s, each ran into difficulties. Over the course of the 1980s, all were fundamentally transformed. The result was a more inclusive-indeed, virtually globaland heightened trend toward international economic integration.

The Bretton Woods monetary order was strained by the late 1960 . This was primarily due to divergence between monetary conditions in the rest of the industrial world, on the one hand, and the United States, on the other. U.S. spending on the Vietnam War and expanded social programs were contributing to a higher rate of inflation in the United States than in Europe, which undermined confidence in the dollar. Austerity measures could have brought down inflation and restored confidence, but the U.S. government was reluctant to sacrifice its domestic macroeconomic policy autonomy to maintain the gold-dollar link, even if this link was the centerpiece of the Bretton Woods monetary system. In August 1971, the United 
States broke the link and devalued the dollar, ending the Bretton Woods era of fixed but adjustable exchange rates.

Another source of tension in the Bretton Woods system was, ironically, due to its success in rekindling international financial markets. While foreign direct investment had continued through the postwar period, international financial flows had effectively stopped in 1929 and stayed minimal until the 196os. As macroeconomic stability and economic growth were restored, financial institutions rediscovered foreign operations. By the early 1970s, international financial markets were large and growing, and the increased level of international financial flows helped undermine the fixed exchange rate regime by heightening speculative pressures on some currencies (including the U.S. dollar).

Once the Bretton Woods exchange rate arrangement ended, most major currencies began floating freely against one another. This loosened the previous monetary straitjacket, and a bout of inflationary pressures ensued. On top of this, in 1973 a cartel of oil producing nations (the Organization of Petroleum Exporting Countries or OPEC) quadrupled the price of petroleum, putting further upward pressure on prices. A deep recession in 1973-75 led to an unaccustomed mixture of high unemployment and high inflation-stagflation, as it was called. Inflation continued to rise, aggravated by another round of OPEC oil price increases in 1979-80.

The rebirth of international finance also made foreign lending newly available to developing countries, which had been frozen out of capital markets for forty years, and a burst of LDC borrowing ensued. By the early 1980s, a dozen or so developing countries had accumulated substantial debts to commercial banks in Europe, North America, and Japan.

Macroeconomic difficulties came to a head after 1979. The developed countries began to adopt more contractionary monetary policies to slow the rate of inflation. This led to extremely high interest rates and several years of recession. The spike in interest rates and global recession threw the LDC debtors into a severe debt crisis, which took many of them the better part of the decade to resolve. Meanwhile, while inflation was brought down in the advanced capitalist countries, unemployment remained at very high levels. The centrally planned economies, too, had been experiencing stagnant growth, and their economic and political systems came under ever greater strain.

In this crisis atmosphere, the developed countries gradually moved to recommit themselves to a market orientation and international economic openness. Governments exercised greater monetary restraint, deregulated many economic activities, and privatized previously public enterprises. The trend was epitomized by the policies of British Prime Minister Margaret Thatcher and U.S. President Ronald Reagan, who made the case for less government involvement in their respective economies. Reagan did so, anomalously, while running up enormous budget deficits in the United States. Nonetheless, and despite such setbacks as a costly banking crisis, by the mid-1980s the developed capitalist countries had made clear their reinforced dedication to an integrated international economy. 
The developing countries, for their part, emerged from debt and related crises with a new-found orientation toward international markets. To be sure, some few LDCs, especially in East Asia, had been following an export-led strategy, but until the 1980 os ISI had been the almost universal policy choice of developing nations. The debt and oil crises, along with the accumulated problems of relatively closed markets in an increasingly open world economy, led almost every country in Latin America, Africa, and Asia to jettison the prior inward orientation in favor of much more economic openness to the rest of the world. Developed and developing capitalist countries continued to reduce barriers to trade and investment, leading to a characterization of the era as one of "globalization."

The most stunning development on the path to globalization was the collapse of the centrally planned economies. The economic problems of the late $1970 \mathrm{~s}$ and early 1980 os eventually drove these countries away from central planning and toward international markets. China and Vietnam were the first to move, in 1979: while maintaining communist rule, both governments reoriented their economies toward exporting to the capitalist world. After 1985, the Soviet Union embarked on an attempt at gradual reform, which was quickly overtaken by events as the country's social and political system unraveled. After the Soviet Union collapsed in 1991, the entire Soviet bloc quickly gave up central planning and moved toward capitalism at speeds varying from gradual to breakneck.

Along with globalization came a renewed interest in regional economic blocs. The European Union (EU) added a whole host of new members, until it encompassed virtually all of Europe. Meanwhile, by 1992 the EU had put in place a single market that eliminated barriers to the movement of goods, capital, and people and that harmonized the regulation of investment, migration, product and production standards, professional licensing, and many other economic activities. A subset of EU members went a step further in 1999, creating a single currency, the euro, and a common European Central Bank. The United States, Canada, and Mexico formed a free trade area in 1994, as did Brazil, Argentina, Uruguay, and Paraguay. All over the world, countries rushed to open their borders, increase their exports, attract foreign capital, and strengthen their economic ties with each other.

By the beginning of the twenty-first century, the modern world economy looked strikingly similar to the classical order of the beginning of the twentieth century. International trade, investment, and finance were generally free from government restrictions. Most governments limited their intervention in markets and in international economic transactions. Migration was less free than it had been, and there was no overarching monetary standard, but otherwise there were many similarities to conditions a century earlier. Capitalism was global, and the globe was capitalist.

Global capitalism had, however, changed profoundly in the intervening years. Today, there is substantial government involvement in the economy, both in macroeconomic demand management and in the provision of a wide array of social insurance and other social programs. This is true of all developed countries and of many developing countries as well. The social democratic welfare state is now the 
norm rather than a novelty, and despite periodic objections it seems unchallenged as the standard organizational form of a modern capitalist political economy.

Just as contemporary capitalism incorporates substantial government supervision of national economic activities, it is also characterized by a dense network of international institutions. Some are regional, such as the European Union. Many are global, such as the IMF and the WTO. The informal cooperative arrangements of the gold standard era have given way to a much more complex array of formal international organizations.

However successful the contemporary economic order may be, it has not eliminated problems that have plagued capitalism since its beginnings. Foremost among these is the recurrence of periodic crises. A deep recession that began late in 2007 served as a reminder that financial and commercial ties among countries can transmit crises-even panics-from market to market with lightning speed. The crisis of 2007-10 also highlights the role of international financial flows, as it was in large part the result of a decade of very substantial cross-border lending and borrowing (Chinn and Frieden 2011). Financial and currency crises, it seems, are the price of open financial markets.

Although contemporary capitalism has been associated with rapid economic growth in many parts of the world-most strikingly, in communist-ruled Chinathere are still many parts of the developing world that remain mired in poverty. Whether this is due to excessive or insufficient reliance on markets or excessive or insufficient integration into the world economy remains a topic of hot debate. This is not surprising. It is almost certainly in the nature of capitalist political economies that there will be enduring conflicts over how and how much government should intervene in markets and how tightly and on what terms national economies should be tied to the world economy.

Over the past five centuries, capitalism has gone from being a novel economic system in a small region in Western Europe to being the prevailing form of economic organization in the whole world. The rise and eventual triumph of capitalism on a global scale has been associated with the most rapid economic growth in world history. It has also been associated with spectacular crises, wrenching conflicts, and a great and growing gap between the world's rich and the world's poor. Global capitalism holds out the hope of extraordinary social and economic advances, but it must address its weaknesses to realize these advances.

\section{Notes}

1. Rostovtzeff (1960) is the best-known argument for Rome's capitalism. Temin (2006) presents strong evidence for the operation of markets in the Roman empire but does not explicitly consider whether the society should be considered capitalist.

2. Cited in Viner (1948).

3. On a more arcane but still important note, as Keynes pointed out (1936, chapter 23), the mercantilist emphasis on bullion and on a trade surplus served to increase the 
money supply (in a specie-based monetary system) and to reduce borrowing costs. In societies heavily oriented toward entrepreneurial activities and novel endeavors, the "shortage of money" (high interest rates) was seen as a major brake on progress. In fact, some of the protectionist measures associated with mercantilism may have been triggered by the emphasis on increasing the money supply to lower interest rates, which would of course also have raised domestic prices.

4. Classic analyses are Ekelund and Tollison (1981) and Ekelund and Tollison (1997).

5. Smith (1776, Book Four).

6. For the definitive analysis, see Schonhardt-Bailey (2006).

7. The remainder of this essay draws loosely on material in Frieden (2006). See that reference for many more details.

8. Maddison (1995, p. 64).

9. Stamp (1979); Mathias and Pollard (1989, p. 56); Maddison (2001, p. 95).

10. Maddison (1995, p. 38). For an excellent survey of the period, see Marsh (1999).

11. O'Rourke and Williamson (1999, p. 209).

12. See, for example, Estevadeordal et al. (2003) and López-Córdova and Meissner (2003).

13. Bordo and Rockoff (1996, pp. 389-428).

14. Eichengreen (1992); Eichengreen and Flandreau (1997). The presentation here is greatly simplified. Governments generally tried to manage their economies so as to avoid major gold flows. This could involve trying to retain gold by raising interest rates, which would tend to keep money at home to take advantage of the higher rate of return. Or it could involve trying to brake domestic wages, prices, and profits, so as to make exports more competitive. Nonetheless, these policies had their origin in the pressures that being on gold exerted on national economies and national governments.

15. O'Rourke and Williamson (1999, pp. 43-53). See also Capie (1983).

16. The classic summary of the technological aspects of the process is Landes (1969, pp. 231-358).

17. Eichengreen (1992) is the canonical analysis of the period.

18. uggie (1982) is the classic statement of the argument.

19. Maddison (2001).

\section{REFERENCES}

Bordo, Michael, and Hugh Rockoff. "The Gold Standard as a 'Good Housekeeping Seal of Approval.” Journal of Economic History 56 (June 1996): 389-428.

Capie, Forrest, H. "Tariff Protection and Economic Performance in the Nineteenth Century." In Policy and Performance in International Trade, ed. John Black and L. Alan Winters1-24. London: Macmillan, 1983.

Chinn, Menzie, and Jeffry Frieden. Lost Decades: The Making of America's Debt Crisis and the Long Recovery. New York: Norton, 2011.

Eichengreen, Barry. Golden Fetters: The Gold Standard and the Great Depression, 1919-1939. New York: Oxford University Press, 1992.

Eichengreen, Barry, and Marc Flandreau, eds. The Gold Standard in Theory and History. New York: Routledge, 1997.

Ekelund, Robert B., and Robert D. Tollison. Mercantilism as a Rent-Seeking Society. College Station: Texas A\&M University Press, 1981.

Ekelund, Robert B., and Robert D. Tollison. Politicized Economies: Monarchy, Monopoly, and Mercantilism. College Station: Texas A\&M University Press, 1997. 
Estevadeordal, Antoni, Brian Frantz, and Alan M. Taylor. "The Rise and Fall of World Trade, 1870-1939." Quarterly Journal of Economics 118 (May 2003): 359-407.

Fisher, Irving. "The Debt-Deflation Theory of Great Depressions.” Econometrica 1 (Oct. 1933): 337-357.

Frieden, Jeffry. Global Capitalism: Its Fall and Rise in the Twentieth Century. New York: Norton, 2006.

Hochschild, Adam. King Leopold's Ghost. Boston: Houghton Mifflin, 1998.

Keynes, John Maynard. The General Theory of Employment, Interest and Money. London: Macmillan, 1936.

Landes, David. The Unbound Prometheus: Technological Change and Industrial Development in Western Europe from 1750 to the Present. Cambridge: Cambridge University Press, 1969.

López-Córdova, J. Ernesto, and Christopher M. Meissner, 2003. "Exchange-Rate Regimes and International Trade: Evidence from the Classical Gold Standard Era." American Economic Review 93 (March 2003): 344-353.

Maddison, Angus. Monitoring the World Economy 1820-1992. Paris: OECD, 1995.

Maddison, Angus. The World Economy: A Millennial Perspective. Paris: OECD, 2001.

Marsh, Peter. Bargaining on Europe: Britain and the First Common Market 1860-1892. New Haven, Conn.: Yale University Press, 1999.

Mathias, Peter, and Sydney Pollard. "European Trade Policy, 1815-1914." In The Cambridge Economic History of Europe (vol. 8): The Industrial Economies: The Development of Economic and Social Policies, ed. Peter Mathias and Sidney Pollard, 1-160. Cambridge: Cambridge University Press, 1989.

O'Rourke, Kevin, and Jeffrey Williamson. Globalization and History: The Evolution of a Nineteenth-Century Atlantic Economy. Cambridge, Mass.: MIT Press, 1999.

Rostovtzeff, Mikhail. Rome. New York: Oxford University Press, 1960.

Ruggie, John G. "International Regimes, Transactions, and Change: Embedded Liberalism in the Postwar Economic Order." International Organization 36 (March 1982): 379-415.

Schonhardt-Bailey, Cheryl. From the Corn Laws to Free Trade: Interests, Ideas and Institutions in Historical Perspective. Cambridge, Mass.: MIT Press, 2006.

Smith, Adam. An Inquiry into the Nature and Causes of the Wealth of Nations. New York: Modern Library, 1937 (1776).

Stamp, A. H. A Social and Economic History of England from 1700 to 1970. London: Research Publishing, 1979.

Temin, Peter. "The Economy of the Early Roman Empire." Journal of Economic Perspectives 20 (Winter 2006): 133-151.

Viner, Jacob. "Power versus Plenty as Objectives of Foreign Policy in the Seventeenth and Eighteenth Centuries." World Politics 1 (Oct. 1948): 1-29. 